Our Nature
Journal homepage: http://nepjol.info/index.php/ON $\begin{gathered}\text { ISSN: 1991-2951 (Print) } \\ \text { ISSN: 2091-2781 (Online) }\end{gathered}$

\title{
Bio-chemical characterization of rhizobia isolated from root nodules of Velvet bean (Mucuna pruriens L.)
}

\author{
Som Prasad Paudyal* and Vimal NP Gupta \\ Department of Botany, Trichandra Multiple College, Tribhuvan University \\ Ghantaghar, Kathmandu, Nepal \\ ${ }^{*}$ E-mail: paudyalsp@yahoo.com
}

\begin{abstract}
Rhizobia are the symbiotic bacteria found in the soil which have potential ability to convert atmospheric di-nitrogen into usable form. A total of ten rhizobial strains were isolated from the root nodules of a medicinal legume Mucuna pruriens (L.) that commonly grow in the foothills of the Himalaya. All the ten strains isolated from different locations of same area were morphologically, biochemically and physiologically characterized based on the Bergey's Manual of systematic Bacteriology. They were tested for the antibiotics sensitivity. The isolates showed high sensitivity to amoxicillin and least to erythromycin. Authentication test was done in eleven legumes but shown nodulations only in Trigonella foenum-graecum, Мисиna pruriens and Medicago sativa. The morphology, physiology, biochemical and infection test studies carried out justifies that the bacteria isolated belonged to the species of Rhizobium meliloti.
\end{abstract}

Key words: Symbiotic bacteria, Trigonella foenum-graecum, Medicago sativa

DOI: http://dx.doi.org/10.3126/on.v15i1-2.18788

Manuscript details: Received: 20.07.2016 / Accepted: 02.06.2017

Citation: Paudyal, S.P. and V. NP Gupta 2017. Bio-chemical characterization of rhizobia isolated from the root nodules of Velvet bean (Mucuna pruriens L.). Our Nature 15(1-2): 7-12. DOI: http://dx.doi.org/10.3126/on.v15i1-2.18788

Copyright: $\odot$ Paudyal and Gupta 2017. Creative Commons Attribution - Non Commercial 4.0 International License.

\section{Introduction}

Rhizobia are traditional soil bacteria because they possess the potential ability to fix atmospheric nitrogen by establishing symbiotic relationship with root nodule formation. The Rhizobium legume symbiosis because of its agricultural importance has got continuous research support worldwide. A great number of rhizobia being able to form nodules have not been examined. Most of those that have not been examined are from tropical areas (De Faria et al., 1989). Therefore, current taxonomy and phylogeny of rhizobia are based on only $15 \%$ of the 750 genera of legumes that has been explored so far. Rhizobia are specific to particular legume; therefore, it is essential to identify and characterize these organisms by morphological, physiological and biochemical basis to obtain their exact taxonomic position. The biochemical characterization of root nodulating bacteria still remains the only valid tests for establishing the identity of Rhizobium. Nevertheless, there have been reports from time to time (Graham and Parker, 1964; Kleczkowska et al., 1968; Skinner, 1977) on the usefulness of certain cultural and biochemical characteristics in the systematics of Rhizobium.

Legumes are very important both ecologically and agriculturally because they are responsible for the substantial part of the global flux of nitrogen from atmospheric $\mathrm{N}_{2}$ to fixed forms such as ammonia, nitrate and organic nitrogen. Atmospheric nitrogen fixed symbiotically by the association between Rhizobium 
species and legume represents a renewable source of N for agriculture (Peoples M.B., et al., 1995). Values estimated for various legume crops and Pasteur species are often impressive, commonly falling in the range $200-300 \mathrm{~kg}$ of $\mathrm{Nha}^{-1} \mathrm{Yr}^{-1}$ (Peoples M.B., et al., 1995). Yield increase of crops planted after harvesting of legumes is often equivalent to those expected from the application of $30-80 \mathrm{Kg}$ of fertilizer $\mathrm{Nha}^{-1}$ (Zahran, 1999).

At present time rhizobia are divided into 5 genera with 38 species including Azorhizobium, Bradyrhizobium, Mesorhizobium, Rhizobium and Sinorhizobium. Phylogenetically these bacteria belong to the $\alpha$-sub-class of proteobacteria (Young and Haukka, 1996).

\section{Materials and methods}

Bacterial strains were isolated from the root nodules of Mucuna pruriens growing wildly on the foothills of the Himalaya according to Vincent (1970). Ten different strains were isolated and were characterized according to Bergey's manual of Determinative Bacteriology (Holt et al., 1994). The cultures were incubated on Yeast Extract Mannitol Agar (YEMA) at $28 \pm$ $1^{\circ} \mathrm{C}$. The isolated strains were stored in YEMA slants at $4^{\circ} \mathrm{C}$.

Morphology was determined by compound microscope through Gram staining. Generation time was calculated in YEM broth from the absorbance at 420nM recorded after every $2 \mathrm{hrs}$. at $28 \pm 1{ }^{\circ} \mathrm{C}$. Catalase activity was determined according to Graham and Parker (1964). The ability to hydrolyze urea and gelatin were estimated according to Lindstrom and Lehtomaki (1988). Growth on Hofer's alkaline medium was done according to Hofer (1935), growth on Glucose Peptone Agar (GPA) was tested according to Kleczkowska et al. (1968). DNA base composition was studied according to Murmur and Doty (1962). Antibiotic resistance was detected using antibiotic discs. Carbon sources utilization by different carbohydrates were substituted for mannitol.

Isolates were tested for nodulation on their original hosts. Seedlings were grown on agar slants. Exponentially grown cultures $\left(10^{8}\right.$ cells $\mathrm{ml}^{-1}$ ) were inoculated during the seedling stage.

\section{Results and discussion}

All the strains isolated $\left(\mathrm{MPR}_{1}-\mathrm{MPR}_{10}\right)$ were fast growing, motile, Gram negative, rod shaped with mean generation time 3.2 - 3.8 hrs (Table 1). The colonies on YEMA were circular, non-spreading, translucent, convex, smooth, entire and odourless with 2 - $4 \mathrm{~mm}$ in diameter after $48 \mathrm{hrs}$. of incubation at $28 \pm 1{ }^{\circ} \mathrm{C}$. These morphological characteristics approaches closer to the genus Rhizobium as described by Jordan and Allen (1974).

No growth was observed on Glucose Peptone Agar (GPA) medium. Acid productions, ability to grow on Hofer's alkaline medium, ability of strains to precipitate calcium glycerophosphate were positive. Catalase activity, reduction of 2,3,5 triphenyl tetrazolium chloride (TTC), inability to utilize citrate with negative gelatinase activity were all positive for rhizobial strains as suggested by Kleczkowska $e t$ al. (1968), Deshwal and Chaubey (2014). Baoling et al. (2007) reported from the analysis of colony morphology that the $\mathrm{pH}$ of the medium (solid) and broth (liquid) during growth of the

Table 1. Biochemical characterization of the strains from Mucuna.

\begin{tabular}{|c|c|c|c|c|c|c|c|c|c|c|}
\hline \multirow{2}{*}{ Tests } & \multicolumn{10}{|c|}{ Strains of rhizobia } \\
\hline & MPR $_{1}$ & $\mathbf{M P R}_{2}$ & $\mathbf{M P R}_{3}$ & $\mathbf{M P R}_{4}$ & $\mathrm{MPR}_{5}$ & $\mathbf{M P R}_{6}$ & $\mathbf{M P R}_{7}$ & MPR8 & MPR9 & $\mathbf{M P R}_{10}$ \\
\hline Gram stain & -ve & -ve & -ve & $-\mathrm{ve}$ & -ve & -ve & -ve & -ve & -ve & -ve \\
\hline Growth on GPA & - & - & - & - & - & - & - & - & - & - \\
\hline Acid production & + & + & + & + & + & + & + & + & + & + \\
\hline Growth on HAM & + & + & + & + & - & + & + & + & - & + \\
\hline Urea hydrolysis & + & - & + & + & + & + & + & + & - & + \\
\hline Growth on $8 \% \mathrm{KNO}_{3}$ & + & + & + & - & + & + & + & + & + & + \\
\hline Citrate utilization & - & - & - & - & - & - & - & - & - & - \\
\hline Catalase activity & + & + & + & + & + & + & + & + & + & + \\
\hline Ppt. with Calcium glycerophosphate & + & + & + & + & + & + & + & + & + & + \\
\hline $2 \% \mathrm{NaCl}$ tolerance & + & + & + & + & - & + & + & + & + & + \\
\hline Generation time $(\mathrm{h})$ & 3.46 & 3.6 & 3.8 & 3.5 & 3.45 & 3.3 & 3.6 & 3.54 & 3.2 & 3.7 \\
\hline Reduction of $2,3,5$ TTC & + & + & + & + & + & + & + & + & + & + \\
\hline Gelatinase activity & - & - & - & - & - & - & - & - & - & - \\
\hline
\end{tabular}

(-ve) Gram negative, (-) No growth observed, (+) Growth observed 
isolates was changed from $\mathrm{pH} 7.0$ to 6.0 thus showing the production of acid which is the characteristic of rhizobia. Different carbon sources used (Table 2) showed that no strains could grow on starch but other carbon sources used showed good growth. Vaishya and Senoria (1972) also observed great variations within the strains of Cicer-rhizobia of Indian origin in the utilization of carbohydrate substrates. Kucuk et al. (2006) also have reported that rhizobial strains were able to utilize glucose and sucrose more efficiently than YEM medium. Niste et al. (2015) also reports the use of wide range of carbohydrates for Rhizobium leguminosarum bv. phaseoli and Sinorhizobium meliloti. Rhizobia isolated to date differ significantly in carbohydrate metabolism and substrate utilization. Fast growing Rhizobium strains possesses NADP-linked 6-phosphogluconatedehydrogenase activity and metabolite a wider range of carbohydrates (Zhang et al., 1991).

The average $\mathrm{G}+\mathrm{C}$ (Guanine + Cytosine) content of DNA was $62.8 \mathrm{~mol} \%$. The rhizobial species usually have $\mathrm{G}+\mathrm{C}$ values in the range of
59 - 64 mol\% (Chen et al., 1988). Delay and Russel (1965) also studied the DNA base composition of Rhizobium which showed the range of 59-63 mol\% corresponding to Rhizobium leguminosarum and Rhizobium meliloti group of Graham (1963). The strains of rhizobia based on generation time, flagellar arrangement, DNA base composition and many other biochemical characteristics (Jordan and Allen, 1974) have been classified into two broad groups: (a) fast growers - peritrichous strains with $\mathrm{G}+\mathrm{C} \mathrm{mol} \%$ in the range of $59-63 \mathrm{~mol} \%$ and (b) slow growers with sub polar flagellated strains with $\mathrm{G}+\mathrm{C}$ mol\% in the range of 62.8 $65.5 \mathrm{~mol} \%$.

On the medium containing mannitol amended with brom thymol blue (BTB) dye, the strains found to produce acid by changing the blue colour of the media to yellow. Brockwell et al. (1966) have reported that acid or alkali production on mannitol was dependent of the soil from where rhizobia were isolated from Trifolium and Lotus. The rhizobial species associated with many of the tropical legumes

Table 2. Carbon source utilization by the strains from Mucuna.

\begin{tabular}{lccccccccccc}
\hline \multirow{2}{*}{ Carbohydrates } & \multicolumn{10}{c}{ Strains of rhizobia } \\
\cline { 2 - 9 } & MPR & MPR & MPR & MPR & MPR5 & MPR6 & MPR & MPR8 & MPR9 & MPR 10 \\
\hline Dextrose monohydrate & + & + & + & + & + & + & + & + & & + & + \\
Sucrose & + & + & + & + & + & + & + & + & + & + \\
Lactose & + & + & + & + & + & + & + & + & + & + \\
Maltose & + & + & + & + & + & + & + & + & + & + \\
Rhamnose & + & + & + & + & + & + & + & + & + & + \\
L-Arabinose & + & + & + & + & + & + & + & + & + & + \\
D(+) Trehalose & + & + & + & + & + & + & + & + & + & + \\
Starch & - & - & - & - & - & - & - & - & - & - \\
Fructose & + & + & + & + & + & + & + & + & + & + \\
\hline
\end{tabular}

(+) Growth occurred, (-) No Growth occurred

Table 3. Antibiotic resistant studies on the strains from Mucuna.

\begin{tabular}{|c|c|c|c|c|c|c|c|c|c|c|c|}
\hline \multirow[b]{2}{*}{ Antibiotics } & \multicolumn{11}{|c|}{ Strains of rhizobia } \\
\hline & $\underline{\underline{z}}$ & $\underline{\underline{z}}$ & $\underline{\underline{a}}$ & $\sum^{\frac{\pi}{a}}$ & $\sum^{\infty}$ & $\sum^{20}$ & $\hat{\underline{a}}$ & $\sum_{\Sigma}^{\infty}$ & $\hat{z}$ & $\sum^{0}$ & $\begin{array}{c}\text { Diameter of inhibition } \\
\text { zone }(\mathbf{c m})\end{array}$ \\
\hline Neomycin & + & + & + & + & + & + & + & + & + & + & 1.5 \\
\hline Erythromycin & + & + & + & $\mathrm{R}$ & + & + & + & + & $\mathrm{R}$ & + & 1.0 \\
\hline Gentamycin & + & + & + & + & + & + & + & + & + & + & 1.5 \\
\hline Ampicillin & $\mathrm{R}$ & $\mathrm{R}$ & $\mathrm{R}$ & $\mathrm{R}$ & $\mathrm{R}$ & $\mathrm{R}$ & $\mathrm{R}$ & $\mathrm{R}$ & $\mathrm{R}$ & $\mathrm{R}$ & - \\
\hline Carbenicillin & $\mathrm{R}$ & $\mathrm{R}$ & $\mathrm{R}$ & $\mathrm{R}$ & $\mathrm{R}$ & $\mathrm{R}$ & $\mathrm{R}$ & $\mathrm{R}$ & $\mathrm{R}$ & $\mathrm{R}$ & - \\
\hline Tetracycline & + & + & $\mathrm{R}$ & + & + & + & $\mathrm{R}$ & + & + & + & 2.0 \\
\hline Chloramphanicol & + & + & + & + & + & + & + & + & + & + & 1.2 \\
\hline Kanamycin & + & + & + & + & + & + & + & + & + & + & 1.2 \\
\hline Bacitracin & $\mathrm{R}$ & $\mathrm{R}$ & $\mathrm{R}$ & $\mathrm{R}$ & $\mathrm{R}$ & $\mathrm{R}$ & $\mathrm{R}$ & $\mathrm{R}$ & $\mathrm{R}$ & $\mathrm{R}$ & - \\
\hline Nalidixic acid & $\mathrm{R}$ & $\mathrm{R}$ & $\mathrm{R}$ & $\mathrm{R}$ & $\mathrm{R}$ & $\mathrm{R}$ & $\mathrm{R}$ & $\mathrm{R}$ & $\mathrm{R}$ & $\mathrm{R}$ & - \\
\hline Furadolizone & $\mathrm{R}$ & $\mathrm{R}$ & $\mathrm{R}$ & $\mathrm{R}$ & $\mathrm{R}$ & $\mathrm{R}$ & $\mathrm{R}$ & $\mathrm{R}$ & $\mathrm{R}$ & $\mathrm{R}$ & - \\
\hline Nistatine & $\mathrm{R}$ & $\mathrm{R}$ & $\mathrm{R}$ & $\mathrm{R}$ & $\mathrm{R}$ & $\mathrm{R}$ & $\mathrm{R}$ & $\mathrm{R}$ & $\mathrm{R}$ & $\mathrm{R}$ & - \\
\hline Amoxycillin & + & + & + & + & + & + & + & + & + & + & 3.5 \\
\hline
\end{tabular}

(+) Sensitive, (R) Resistant 
like Cajanus, Sesbania have also been reported to be acid producing in mannitol (Johnson and Allen, 1952). Paudyal and Gupta (1993) also reports the acid producing properties in fast growing Rhizobium phaseoli isolated from Phaseolus vulgaris in Kathmandu soils. The study on the antibiotic resistance showed that the strains were found resistant to ampicillin, carbanicillin, bacitracin, nalidixic furadolizone and nistatine (Table 3). Twenty percent of the isolates were resistant to erythromycin, tetracycline and chloramphanicol. The maximum area of inhibition was recorded $3.5 \mathrm{~cm}$ (diameter) by amoxycillin in the strain. It was reported by various workers that the fastgrowing strains of rhizobia are less tolerant than do the slow growers (Gauri et al., 2011).

Bacterial growth was directly influenced by the change in temperature as it controls the cellular activities. During the present study, the optimum temperature for growth recorded was $28 \pm 1{ }^{\circ} \mathrm{C}$. As the incubation temperature increased, a decreased growth was observed. The strain $\mathrm{MPR}_{8}$ showed reduced CFU counts at $45^{\circ} \mathrm{C}$, whereas the other strains could not survive at that temperature. Karanjan and Wood (1988) reported that rhizobia from hot dry areas are relatively more temperature and desiccation tolerant than the strains from the Polar Regions. Several temperature tolerant $\mathrm{N}_{2}$ fixing rhizobial strains has been described that can grow up to $40^{\circ} \mathrm{C}$ (Hungria et al., 2000). Various workers have reported that temperature tolerance of Rhizobium from different habitats and hosts found that very few strains could grow above $40^{\circ} \mathrm{C}$ (Trotman and Weaver, 2000). Segovia et al. (1991) observed that high soil temperature can also contribute to the frequency of noninfective isolates in the $80 \%$ growth restriction on the strains of rhizobia at lower temperatures below $0{ }^{\circ} \mathrm{C}$ either by slow or fast-growing strains (Graham, 1992).

The tolerances to $\mathrm{pH}$ from the isolated strains were also observed. The optimum $\mathrm{pH}$ for the strains Rhizobium meliloti $\left(\mathrm{MPR}_{8}\right)$ was observed at 7.0. The strains showed better growth at alkaline $\mathrm{pH}$ than in acidic ones. The reduction in CFU counts $\mathrm{ml}^{-1}$ of $\mathrm{MPR}_{8}$ at $\mathrm{pH} 8.0$, 10 and 11.0 were $12 \%, 13 \%$ and $19 \%$, respectively after $24 \mathrm{hrs}$ of growth compared to control $(\mathrm{pH} 7.0)$. The reduction at lower $\mathrm{pH}$ 's $6.0,5.0$ and 2.0 were $13 \%, 46.7 \%$ and by $54 \%$, respectively. The survival and growth of rhizobia were affected by soil acidity as well as the process of nitrogen fixation. The strains we have tested showed similarities in $\mathrm{pH}$ tolerance. The optimum $\mathrm{pH}$ for growth was 7.0. The fastgrowing strains were reported to be less tolerant to the lower pH's $(4.0-6.0)$ by Graham et al. (1994). In our study, it was found that the strains were highly affected by acidic $\mathrm{pH}$ rather than alkaline ones due to our strains were acid producing. Same types of results were reported by Brockwell et al. (1991). Elizabeth et al. (2000) screened the acid tolerant strains of Rhizobium leguminosarum for the improvement of clover plant and observed that the effectiveness of the strains showed on gradual loss. It is essential to develop acid tolerant strains of rhizobia to inoculate legumes under acidic soil conditions that will ensure the establishment of efficient symbiosis (Correa et al., 1999).

The strains isolated were subjected to cross inoculation study and found that the isolates showed nodulation on Mucuna pruriens, Trigonella foenum-graecum and Medicago sativa (Table 4).

Table 4. Cross inoculation studies using the strains from Mucuna.

\begin{tabular}{|c|c|c|c|c|c|c|c|c|c|c|}
\hline \multirow{2}{*}{ Host Legumes } & \multicolumn{10}{|c|}{ Strains of rhizobia } \\
\hline & MPR1 $_{1}$ & $\mathbf{M P R}_{2}$ & $\mathbf{M P R}_{3}$ & $\mathbf{M P R}_{4}$ & $\mathbf{M P R}_{5}$ & MPR6 $_{6}$ & $\mathbf{M P R}_{7}$ & MPR8 & MPR9 & $\operatorname{MPR}_{10}$ \\
\hline Pisum sativum & - & - & - & - & - & - & - & - & - & - \\
\hline Vigna mungo & - & - & - & - & - & - & - & - & - & - \\
\hline Vigna radiata & - & - & - & - & - & - & - & - & - & - \\
\hline Phaseolus vulgaris & - & - & - & - & - & - & - & - & - & - \\
\hline Lens culinaris & - & - & - & - & - & - & - & - & - & - \\
\hline Cicer aerietinum & - & - & - & - & - & - & - & - & - & - \\
\hline Medicago sativa & + & + & + & + & + & + & - & + & - & + \\
\hline Mucuna pruriens & + & + & + & + & + & + & + & + & + & + \\
\hline Trigonella foenumgraecum & + & - & + & + & - & - & + & + & + & + \\
\hline Arachis hypogaea & - & - & - & - & - & - & - & - & - & - \\
\hline Trifolium repens & - & - & - & - & - & - & - & - & - & - \\
\hline
\end{tabular}

(+) Nodulation occurred, (-) No nodulation occurred 
It was concluded from the morphological, physiological, biochemical, molecular biological and in vitro infectivity tests were all similar as described by Holt et al. (1994) for rhizobial species. Further their generation time, carbon source utilization, DNA base composition, antibiotic resistance properties confirms to the species of Rhizobium meliloti.

\section{Acknowledgements}

We are thankful to the Department of Botany, Trichandra Multiple College for providing us the instrumental support for the completion of the study. The non-teaching staffs of the department are highly acknowledged.

\section{References}

Baoling, H., L. ChenQun., W. Bo and F. LiQin 2007. A rhizobia strain isolated from root nodule of gymnosperm Podocarpus macrophyllus. Sci. Chin. Ser. C-Life Sci. 50: 1-6.

Brockwell, J., A. Pilka and R.A. Holiday 1991. Soil $\mathrm{pH}$ is a major determinant of New South Wales. Aust. J. Exp. Agric. 31: 211-219.

Brockwell, J., S.K. Asuo and G.A. Rea 1966. Acid production of rhizobia from the genera Trifolium and Lotus. J. Austral. Inst. Agric Sci. 32: 295-297.

Chen, W.X., G.H. Yan and J.L. Li 1988. Numerical taxonomic study of fast growing soybean rhizobia and a proposal that Rhizobium fredii be assigned to Sinorhizobium gen. Nov. Intl. J. Sys. Bacteriol. 38: 392-397.

Correa, O.S., E.A. Rivas and A.J. Barnix 1999. Cellular envelope and tolerance to acidic $\mathrm{pH}$ in Mesorhizobium loti. Current Microbiol. 38: 329-334.

De Faria, S.M., G.P. Lewis, J.I. Sprent, and J.M. Sutherland 1989. Occurrence of nodulation in the Leguminosae. New Phytol. 111: 607-619.

Delay, J.L. and A. Russel 1965. DNA base composition, flagellation and taxonomy of the genus Rhizobium. J. Gen. Microbiol. 41: 8591.

Deshwal, V.K. and A. Chaubey 2014. Isolation and Characterization of Rhizobium leguminosarum from root nodules of Pisum sativum $\mathrm{L}$. J. Acad. Ind. Res. (JAIR) 2(8): 464-467.

Elizabeth, L.J.W., W. O'Hara. Graham, J.G. Howieson and A.R.Glenn 2000. Identification of tolerance to soil acidity in inoculant strains of Rhizobium leguminosarum bv trifolii. Soil Biol. Biochem. 32: 1393-1403.
Gauri, A.K.S., R.P. Bhatt, S. Pant, M.K. Bedi and A. Naglot 2011. Characterization of Rhizobium isolated from root nodules of Trifolium alexandrium. J. Agric. Technol. 7(6): 1705-1723.

Graham, P.H. 1963. Antigenic properties of root nodule bacteria of legumes. Antony Van Leeuenhoek 29: 281-291.

Graham, P.H. 1992. Stress tolerance in Rhizobium and Bradyrhizobium and nodulation under adverse soil conditions. Can. J. Microbiol. 38: 475-484.

Graham, P.H. and C.A. Parker 1964. Diagnostic features in characterization of root nodule bacteria of legumes. Plant and soil 20: 383396.

Graham, P.H., K.J. Draeger, M.J. Ferry, B.E. Hammer, E. Martinez and C. Quinto 1994. Acid pH tolerance in strains of Rhizobium and Bradyrhizobium and initial studies on the basis of acid tolerance of Rhizobium tropicii UMR 1899. Can. J. Microbiol. 40: 198-207.

Hofer, A.W. 1935. Methods for distinguishing between legume bacteria and their most common contaminants. J. American Soc. Agronomy 27: 228-230.

Holt, J.G., R.K. Noel, H.A. Peter, J. Sneath, T. Stanley and T. Williams 1994. Bergey's manual of determinative bacteriology $\left(9^{\text {th }} \mathrm{ed}\right)$. Lippinkott Williams and Wilkins.

Hungria, M., D.S. Andrade and L.M. Chueira 2000. Isolation and characterization of new efficient and competitive beans (Phaseolus vulgaris L) rhizobia in Brazil. Soil Biol. Biochem. 32: 1515-1528.

Johnson, M.D. and O.N. Allen 1952. Nodulation studies with special reference to strains isolated from Sesbania sp. Antony Von Leeuenhoek 18: 1-12.

Jordan, D.C. and O.N. Allen 1974. Genus II Rhizobium In Bergeys Manual of Determinative Bacteriology, $\quad 8^{\text {th }} \quad e d$., (Buchanan, R.E. and N.E. Gibson eds.). The Williams and Wilkins, Co. Baltimore. pp. 262-264.

Karanjan, N.K. and M. Wood 1988. Selecting Rhizobium phaseoli strains for use with beans (Phaseolus vulgaris $\mathrm{L}$ ) in Kenya. Tolerance to high temperature and antibiotic resistance. Plant and Soil 112: 15-22.

Kleczkowska, J., P.S. Nutman, S.A. Skinner and J.M. Vincent 1968. In Identification methods for microbiologists, part-B, (Gibbs, B.M. and D.A. Shapton eds.). pp 51-65. 
Kucuk, C., M. Kivanc and E. Kinaci 2006. Characterization of Rhizobium sp. isolated from Bean. Turk. J. Biol. 30: 127-132.

Lindstrom, K. and S. Lehtomaki 1988. Metabolic properties, maximum growth temperature and phase sensitivity of Rhizobium sp compared with other fast-growing rhizobia. FEMS Microbiological Letters 50: 277-287.

Murmur, J. and P. Doty 1962. Determination of the base composition of deoxyribonucleic acid from its thermal denaturation temperature. $J$. Mol. Biol. 5: 109-118.

Niste, M., R. Vidican, C. Puia, I. Rotar and R. Pop 2015. Isolation and bio-chemical characterrization of Rhizobium leguminosarum bv. trifoli and Sinorhizobium meliloti using API $20 \mathrm{NE}$ and API 20 E. Bulletin USAMAV Series Agriculture 72(1): 173-178. DOI: 10.15835/buasvmcn-agr:11178

Paudyal, S.P. and V.N.P. Gupta 1993. Response of French bean (Phaseolus vulgaris) to locally isolated Rhizobium inoculation in Kathmandu soils. Workshop symposium "Improvement of Soil Fertility” Nanjing, China.

Peoples, M.B., D.F. Herridge and J.K. Ladha 1995 Biological Nitrogen Fixation: an efficient source of nitrogen for sustainable agricultural production. Plant and Soil 174: 3-28.

Segovia, L., D. Pinero, R. Palacios and E. Martinez-Romero 1991. Genetic structure of a soil population of non-symbiotic Rhizobium leguminosarum bv phaseoli type I strain in a new species, Rhizobium etli sp. Nov. Intl. J. Sys. Bacteriol. 43: 374-377.

Skinner, F.A. 1977. An evaluation of the Nile blue test for differentiating rhizobia from agrobacteria. J. Appl. Bacteriol. 43: 43-98.

Trotman, A.P. and R.W. Weaver 2000. Survival of rhizobia on arrow leaf clover seeds under stress of seed coat toxins, heat and desiccation. Plant and Soil 218: 43-47.

Vaishya, U.K. and C.L. Senoria 1972. Specificity and efficiency of Rhizobium culture of Bengal Gram (Cicer aerietinum L). Ind. J. Microbiol. 121: 133-141.

Vincent, J.M. 1970. A Manual for the practical study of root nodule bacteria. IBP handbook no. 15, Blackwell Publication, Oxford, U. K.

Young, J.P.W. and K. Haukka 1996. Diversity and phylogeny of rhizobia. New Phytol. 133: $87-$ 94.

Zahran, H.H. 1999. Rhizobium-Legume symbiosis and nitrogen fixation under severe conditions and in an arid climate. Microbiol. Mol. Biol. Rev. 63(4): 968-989.

Zhang, X.P., M. Karsisto, R. Harper and K. Lindstrom 1991. Diversity of Rhizobium bacteria isolated from root nodules of leguminous trees. Intl. J. Sys. Bacteriol. 41: 104-113. 